\title{
11: 118167082-118125623
}

National Cancer Institute

\section{Source}

National Cancer Institute. 11:118167082-118125623. NCI Thesaurus. Code C42125.

Physical location of DDX6_Gene 